\title{
Study of the improved Sf9 transient gene expression process
}

\author{
Xiao Shen, David L Hacker, Lucia Baldi, Florian M Wurm* \\ From 23rd European Society for Animal Cell Technology (ESACT) Meeting: Better Cells for Better Health \\ Lille, France. 23-26 June 2013
}

\begin{abstract}
Introduction
Insect cells have been widely used for the production of recombinant proteins using recombinant baculovirus for gene delivery [1]. To simplify protein production in insect cells, we have previously described a method, based on transient gene expression (TGE) with cultures of suspension-adapted Sf9 cells using polyethylenimine (PEI) for DNA delivery [2]. Expression of GFP has been realized at high efficiency and a tumor necrosis factor receptor-Fc fusion protein (TNFR-Fc) was produced at a level of $40 \mathrm{mg} / \mathrm{L}$. However, the efficiency of the insect cells TGE system has not been studied and further optimization may improve protein titers. Here, we studied the efficiency of PEI for plasmid delivery in Sf9 cells.
\end{abstract}

\section{Methods}

\section{Cell culture}

Sf- 9 cells were maintained in suspension in TubeSpin ${ }^{\circledR}$ bioreactor 600 at $28^{\circ} \mathrm{C}$ [3].

\section{Sf-9 cells Transfection}

Sf9 cells were transfected as described before [2] using $25 \mathrm{kDa}$ polyethylenimine PEI (Polysciences, Warrington, PA) and an expression vector for GFP or TNFR-Fc. GFP-specific fluorescence was measured $48 \mathrm{~h}$ posttransfection using the GUAVA EasyCyteTM flow cytometer (Millipore, Billerica MA, USA). TNFR-Fc was measured by sandwich ELISA [4].

\section{Estimation of plasmid copy number}

Total DNA was isolated using DNeasy Blood \& Tissue Kit (Qiagen AG, Hombrechtikon, Switzerland) according to the manufacturer's protocol. PCR was executed using the Absolute qPCR SYBR Green ROX reaction mix

\footnotetext{
* Correspondence: florian.wurm@epfl.ch

Laboratory of Cellular Biotechnology, Faculty of Life Sciences, Ecole

Polytechnique Fédérale de Lausanne, CH-1015 Lausanne, Switzerland
}

(Axon Lab AG, Baden-Dättwil, Switzerland) with total cellular DNA as template. The PCR was performed using LightCycler ${ }^{\circledR} 480$ real-time PCR system (Roche Applied Science, Basel, Switzerland). The plasmid copy number was estimated from the standard curve according to the threshold cycle $(\mathrm{Ct})$ of each sample [4].

\section{Cell cycle analysis}

Cells at different times post-transfection were centrifuged and washed with PBS before fixation in 70\% ethanol. Fixed cells were washed with PBS and then stained with Guava Cell Cycle Reagent and analyzed by the GUAVA EasyCyteTM flow cytometer. Cells treated with nocodazole $(50 \mathrm{ng} / \mathrm{mL}, 16 \mathrm{~h})$ and mimosine $(1 \mathrm{mM}, 24$ $\mathrm{h})$ were used as references for determining the positions of the $\mathrm{G} 1$ and $\mathrm{G} 2 / \mathrm{M}$ phases [5].

\section{Results}

\section{Plasmid delivery efficiency in Sf9 cells}

To measure the time course of plasmid DNA delivery, cells were transfected with a GFP expression vector. At different times post-transfection, a complete medium exchange was performed. The percentage of GFP-positive cells was determined for all cultures including a control for which a medium exchange was not performed. All cultures exhibited similar levels of GFPpositive cells meaning that DNA uptake into cells occurred within 10 min of DNA addition (Figure 1A).

To measure the amount of DNA uptake, Sf9 cells were transfected in two different ways with a TNFR-Fc expression vector and the amount of intracellular plasmid was measured by quantitative PCR. On the day of transfection more than $80 \%$ of the plasmid DNA was present within cells with the control transfection while $40 \%$ of the DNA was present within cells following a high-density transfection (Figure 1B). It has been reported that improved plasmid delivery can result in an 


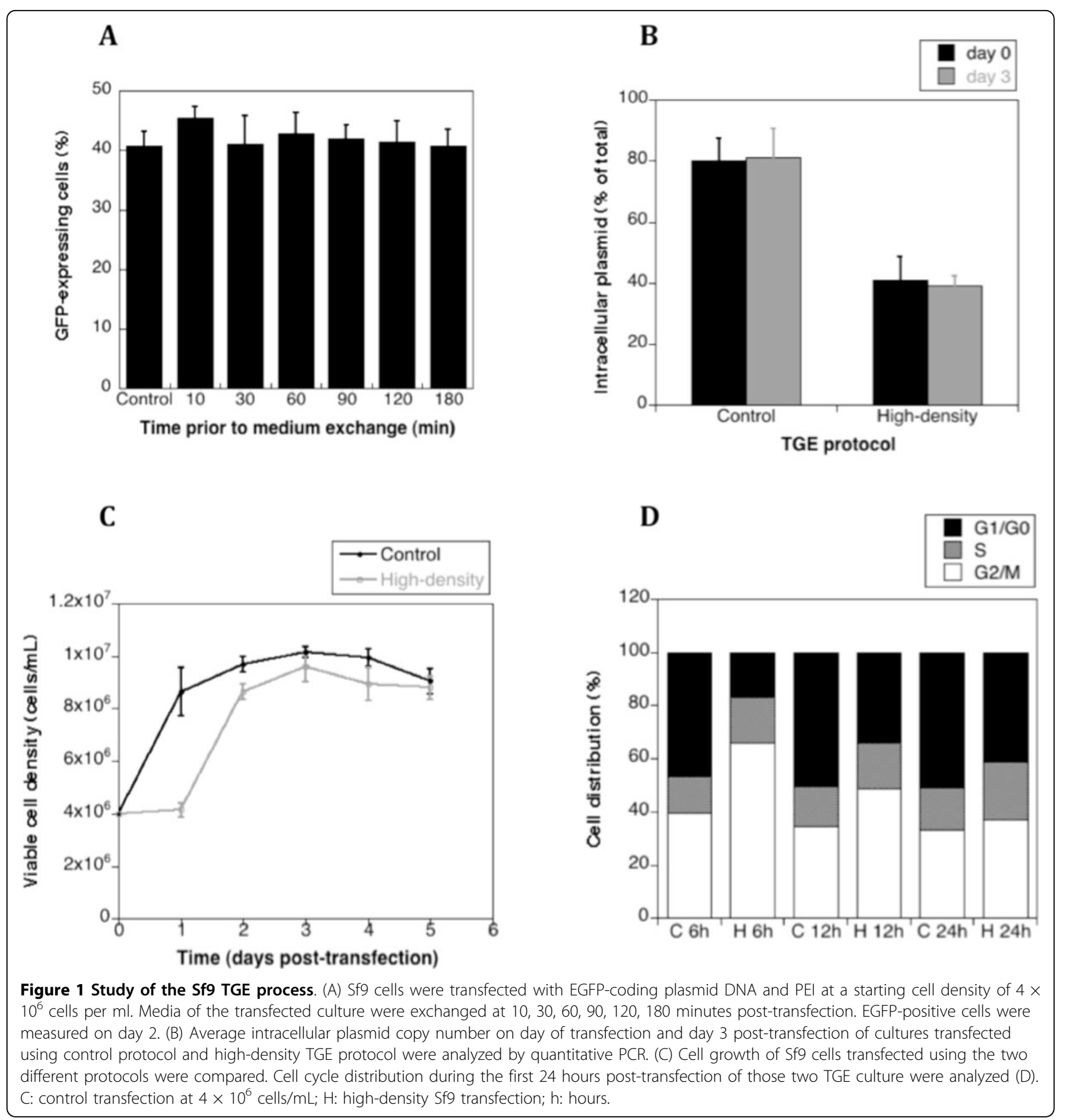

increase in specific and volumetric productivity for HEK 293 cells transfected at high-density [6]. However, in our high-density protocol, plasmid delivery was diminished in comparison to the control (Figure 1B).

Plasmid delivery was not improved, but cell growth was inhibited in an optimized TGE process

Improvement in TGE yields from Chinese hamster ovary cells was achieved by reducing the cell growth rate [5,7]. When the cell growth curve of the optimal TGE process with Sf9 cells was compared with that of the control protocol, we observed a significant decrease of viable cell number, within $24 \mathrm{~h}$ post-transfection (Figure $1 C$ ). This suggested a deregulation in the cell cycle in the initial phase of transfection. The cell cycle distribution was analyzed and an increase of the percentage of cells in the G2/M phase was observed for the highdensity protocol early after transfection (Figure 1D). 
However, the growth inhibition was attenuated by $24 \mathrm{~h}$ post-transfection (Figure 1D). Nevertheless, the temporary cell growth inhibition contributed to yield improvement in our optimal protocol.

\section{Conclusion}

A previously described method for the transient transfection of Sf9 cells was improved. The increase in recombinant protein yield was not due to an increased plasmid delivery after transfection. However, high-density transfection resulted in a significant percentage of cells being blocked in the G2/M phase of the cell cycle for the first $24 \mathrm{~h}$ post-transfection.

Published: 4 December 2013

\section{References}

1. Kost TA, Condreay JP, Jarvis DL: Baculovirus as versatile vectors for protein expression in insect and mammalian cells. Nat Biotechnol 2005, 23:567-575.

2. Shen X, Michel PO, Xie Q, Baldi L, Wurm FM: Transient transfection of insect Sf-9 cells in TubeSpin ${ }^{\circledR}$ bioreactor 50 tubes. BMC Proc 2011, , Suppl 8: P37.

3. Xie Q, Michel PO, Baldi L, Hacker DL, Zhang X, Wurm FM: TubeSpin bioreactor 50 for the high-density cultivation of Sf-9 insect cells in suspension. Biotechnol Lett 2011, 33:897-902.

4. Matasci M, Baldi L, Hacker DL, Wurm FM: The PiggyBac transposon enhances the frequency of $\mathrm{CHO}$ stable cell line generation and yields recombinant lines with superior productivity and stability. Biotechnol Bioeng 2011, 108:2141-2150.

5. Wulhfard S, Tissot S, Bouchet S, Cevey J, De Jesus M, Hacker DL, Wurm FM: Mild hypothermia improves transient gene expression yields several fold in Chinese hamster ovary cells. Biotechnol prog 2008, 24:458-465.

6. Backliwal G, Hildinger M, Hasija V, Wurm FM: High-density transfection with HEK-293 cells allows doubling of transient titers and removes need for a priori DNA complex formation with PEI. Biotechnol Bioeng 2008, 99:721-727.

7. Gorman $\mathrm{CM}$, Howard $\mathrm{BH}$, Reeves R: Expression of recombinant plasmids in mammalian cells is enhanced by sodium butyrate. Nucleic acids res 1983, 11:7631-7648.

doi:10.1186/1753-6561-7-S6-P19

Cite this article as: Shen et al:: Study of the improved Sf9 transient gene expression process. BMC Proceedings 2013 7(Suppl 6):P19.

\section{Submit your next manuscript to BioMed Central and take full advantage of:}

- Convenient online submission

- Thorough peer review

- No space constraints or color figure charges

- Immediate publication on acceptance

- Inclusion in PubMed, CAS, Scopus and Google Scholar

- Research which is freely available for redistribution

Submit your manuscript at www.biomedcentral.com/submit
C Biomed Central 